\title{
Coccidiosis of Goats in Florida, USA
}

\author{
Tyrell B. Kahan*, Ellis C. Greiner \\ College of Veterinary Medicine, University of Florida, Gainesville, USA \\ Email: "kahant@gmail.com, greinere@ufl.edu
}

Received June 2, 2013; revised June 30, 2013; accepted July 5, 2013

Copyright (c) 2013 Tyrell B. Kahan, Ellis C. Greiner. This is an open access article distributed under the Creative Commons Attribution License, which permits unrestricted use, distribution, and reproduction in any medium, provided the original work is properly cited.

\begin{abstract}
Fecal samples from 277 goats on eleven farms in Florida were examined to determine the prevalence and intensity of the multiple species of Eimeria that infect goats in this region. The number of oocysts per gram of feces (OPG) was determined by the modified McMaster technique. Species identification was done following sporulation. Eimeria oocysts were found in $97 \%$ of the fecal samples. Goats less than one year of age shed significantly more oocysts than goats greater than one year of age $(\mathrm{P}<0.01)$. Goats of the Nubian breed had the highest OPG counts when compared to Boer, Boer-Spanish crosses, and Saanen breeds. Nine Eimeria spp. were identified. Eimeria arloingi (91\%), E. ninakohlyakimovae (82\%) and E. alijevi (79\%) were the most prevalent species. Other species present were E. caprina (60\%), E. christenseni (60\%), E. hirci (46\%), E. caprovina (29\%), E. aspheronica (15\%), and E. jolchijevi (9\%).
\end{abstract}

Keywords: Coccidiosis; Eimeria Spp.; Goat; Florida

\section{Introduction}

Goat production has grown in Florida over the last several decades. The majority of the Florida goat industry is characterized by production systems called ranchettes. The popularity of ranchettes was thought to have developed in response to the growth in Florida's human population combined with some people's desire to live in rural areas while working in urban areas. The goat appeared to be ideal for these small-scale producers because it is easy to handle and can convert limited nutritional resources into meat and milk [1].

Coccidiosis, caused by protozoa of the genus Eimeria, is one of the major parasitic diseases influencing the goat industry in many parts of the world including Florida.

The widespread occurrence of coccidiosis in Florida can be attributed to two major factors: favorable climatic conditions and intensive production systems. The warm, moist environment that characterize the subtropical climate of Florida provide optimal conditions for the sporulation of Eimeria oocysts. This results in year-round exposure of goats to infective oocysts [2]. Year-round intensive rearing on improved pastures, which characterizes the production systems of the majority of goat farms in Florida, leads to a greater risk of goats ingesting infective oocysts due to the concentrating effects of confine-

*Corresponding author. ment $[3,4]$.

The production capabilities of the Florida goat industry is constrained by multiple factors including the effects of gastrointestinal parasite infections. Currently, producers are not able to meet the local demand for goat-derived products that is fueled primarily by large immigrant populations. Additionally, it is difficult for Florida goat producers to compete with the prices of goat-derived products imported from other areas like Texas and Australia because of the ability of producers in those regions to produce goats at a lower cost [2]. As coccidiosis is considered to be one of the most economically important diseases of intensively-reared goats worldwide, information to better manage coccidiosis may help Florida producers to increase animal productiveity, lower their production costs and improve their ability to compete with other goat producing regions [5-7]. Therefore, the objective of this study was to determine the prevalence and intensity of infection of Eimeria species in goats in Florida.

\section{Methods and Materials}

Fecal samples were collected individually from the rectum of at least $40 \%$ of each herd from eleven farms in Florida between May and July of 2008. The fecal samples were stored no more than 24 hours at $4^{\circ} \mathrm{C}$ until examined. Two farms produced Boer-Spanish crossbreds 
goats for meat, six farms raised Boer goats for breeder stock and meat, two farms reared Nubians for meat and dairy purposes, and one farm managed a Saanen herd for dairy purposes. Goats examined were categorized into two groups based on age of animal: kids (younger than 1 year) and adults (older than 1 year). The ages of the animals were based on owner records.

The number of oocysts per gram of feces (OPG) was determined by the modified McMaster technique in sodium nitrate solution, with a detection level of 50. To carry out the identification of Eimeria species, samples with >1000 OPG were incubated in 3\% potassium dichromate and aerated daily for at least one week to allow sporulation to occur. Samples were then concentrated by the Sheather's sugar flotation technique. Oocysts were differentiated on the basis of oocyst and sporocyst morphology according to the descriptions and illustrations given by [8,9]. Measurements were made using an ocular micrometer. The slide was scanned in parallel sweeps and the first 100 oocysts seen were identified. If there were fewer than 100 oocysts in the sample, all were identified.

Statistical analyses on all data were carried out using SigmaStat Statistical Software [10]. The analysis of OPG was done using the analysis of variance (ANOVA) to determine differences among breeds and the t-test to determine differences among age groups after the data was transformed using $\log _{e}(\mathrm{FEC}+100)$. The data was log transformed to normalize the data. The Chi-square was used to test the significance of differences among the prevalence found on these farms. Probability of $<0.05$ was regarded as significant.

\section{Results}

Oocysts of Eimeria spp. were found in $97 \%$ of 277 fecal samples of goats. All farms examined had at least one species of Eimeria spp. present. The OPG of kids was significantly higher than adult goats $(\mathrm{P}<0.01)$ (Table 1).

The proportion of animals infected with at least one species of Eimeria spp. was similar among age groups. In adult animals, the Nubian breed had the highest average OPG when compared to the other three breeds (Table 2).

Nine Eimeria species were identified in this study (Table 3). Eimeria arloingi, E. ninakohlyakimovae and E. alijevi were the most prevalent species. Eimeria caprina, E. christenseni, and E. hirci were relatively common species. Eimeria caprovina, E. aspheronica, and E. jolchijvi were the least prevalent species.

Eimeria alijevi and E. hirci infection was significantly more prevalent in adult goats than kids $(\mathrm{P}<0.01)$. Mixed infections were encountered in most of the samples, with up to eight Eimeria species recovered from individual samples.
Table 1. The number and percentage of goats infected and mean counts of Eimeria oocysts per gram (OPG) of goats from Florida.

\begin{tabular}{cccc}
\hline & $\begin{array}{c}\text { Kids } \\
(<1 \text { year old }) \\
\mathrm{n}=126\end{array}$ & $\begin{array}{c}\text { Adult } \\
(>1 \text { year old }) \\
\mathrm{n}=151\end{array}$ & $\begin{array}{c}\text { All goats } \\
\mathrm{n}=277\end{array}$ \\
\hline $\begin{array}{c}\text { No. (\%) of infected } \\
\text { Mean OPG }\end{array}$ & $123(98)$ & $147(97)$ & $270(97)$ \\
$13229^{\mathrm{a}}$ & 2229 & 7232 \\
\hline
\end{tabular}

${ }^{\mathrm{a}}$ Significantly $(\mathrm{P}<0.05)$ different than adult goats.

Table 2. Mean counts of Eimeria oocysts per gram (OPG) in adult goats ( $>1$ year) from Florida by breed.

\begin{tabular}{ccccc}
\hline & $\begin{array}{c}\text { Boer } \\
\mathrm{n}=77\end{array}$ & $\begin{array}{c}\text { Boer-Spanish } \\
\mathrm{n}=47\end{array}$ & $\begin{array}{c}\text { Nubian } \\
\mathrm{n}=20\end{array}$ & $\begin{array}{c}\text { Saneen } \\
\mathrm{n}=7\end{array}$ \\
\hline Mean OPG & 2408 & 844 & $5420^{\mathrm{a}}$ & 443 \\
\hline
\end{tabular}

${ }^{\mathrm{a}}$ Means with differing superscripts differ significantly $(\mathrm{P}<0.05)$ from each other.

Table 3. The prevalence (in percentages) of Eimeria species in goats from Florida.

\begin{tabular}{lccc}
\hline Eimeria species & $\begin{array}{c}\text { Kids } \\
(<1-\text { year old }) \\
\mathrm{n}=77\end{array}$ & $\begin{array}{c}\text { Adults } \\
(>1-y e a r \text { old }) \\
\mathrm{n}=59\end{array}$ & $\begin{array}{c}\text { All goats } \\
\mathrm{n}=136\end{array}$ \\
\hline E. arloingi & 92 & 89 & 91 \\
E. alijevi & $71^{\mathrm{a}}$ & 88 & 79 \\
E. aspheronica & 14 & 17 & 15 \\
E. caprina & 58 & 61 & 60 \\
E. caprovina & 34 & 24 & 29 \\
E. christenseni & 65 & 54 & 60 \\
E. hirci & $38^{\mathrm{a}}$ & 56 & 46 \\
E. jolchejevi & 6 & 12 & 9 \\
E. ninakohlyakimovae & 82 & 81 & 82 \\
\hline
\end{tabular}

${ }^{\mathrm{a}}$ Significantly $(\mathrm{P}<0.05)$ different than adult goats.

\section{Discussion}

The high prevalence of Eimeria spp. encountered in this study is similar to other studies performed in the United States [11-14]. Infections by multiple Eimeria spp. in single animals are also common and tend to characterize the majority of infections exemplified by the multiple infections that have been described in other studies [3, $6,15]$.

The higher intensity of infection of kids when compared to the adult goats in this study was similar to the findings of previous authors $[8,12,16,17]$. These findings further the notion that the number of oocysts shed declines as the animal matures. This decline is most likely due to the development of an immunological resistance that is related to host age and exposure to the parasites. The resistance observed in adult goats appears to be relative rather than absolute as adults continue to shed oo- 
cysts in the feces, which allow them to act as the major source of infection for young, naive animals. Although clinical coccidiosis is usually observed in young animals that have not acquired resistance, the resistance observed in older animals can be overcome by a severe challenge or an immune system diminished sufficiently by stressful conditions to result in clinical disease [5].

The nine species identified in this study were generally similar to the type and number of species found in other parts of the United States. The same nine species found in this study of Florida were found in studies performed in the mid-western United States and in Montana [12,14]. These nine species in addition to E. ahsata were found in Maryland [13].

The dominance of E. arloingi, E. ninakohlyakimovae and E. alijevi in this study is similar to other reports from various geographic and climatic areas $[7,14,15]$. Eimeria arloingi and E. ninakohlyakimovae are the most ubiquitous species worldwide and are also considered to be the most pathogenic species of goats [5]. The relative differences in prevalence of Eimeria species and differences seen in prevalence by age between this study and other studies cannot be explained.

In this study, Nubians had the highest OPG counts when compared to Boers, Boer-Spanish crosses, and Saanens. Although the multiple factors that may affect the results in this study due to possible differences in management practices among the herds should also be considered, differences in intensity of infection among breeds have been reported in other studies. When goats of similar age were compared in a study conducted in Australia, Nubian goats had higher OPG counts than Saanen and Angora breeds [16]. In another study, Nubian goats shed higher OPG daily when compared to Saanens after experimental infection [18].

\section{Conclusion}

The high prevalence of Eimeria oocysts found in the fecal samples of goats in this project indicates that Eimeria infections are very common in goats in Florida. The high prevalence of Eimeria infections, the relatively common practice of intensive rearing and the favorable climatic conditions found in Florida all contribute to the large impact that coccidiosis has on Florida goat production, both clinically and economically. It has been hypothesized that the intensity of Eimeria infection and the incidence of clinical coccidiosis is not as correlated to the intensity of management as it is to strict hygienic practices, parasite management practices (i.e. chemical prophylaxis), and the nutritional status of the herd as it relates to their degree of immunological competence [3, $7,16]$. As the Florida goat industry continues to progress, it is important that Florida producers adopt effec- tive management practices to decrease the development and impact of coccidiosis on their farms.

\section{Acknowledgements}

The authors would like to thank the following: the MerckMerial Summer Research Program for funding this project; the producers for giving the author permission to sample their animals; Brittany Sears, Toni McIntosh, Ashley Setters, Jennifer Burroughs, Dr. Jorge Hernandez and Dr. Max Irsik for their technical assistance.

\section{REFERENCES}

[1] J. Simpson, "Introduction to Florida’s Meat Goat Industry,” University of Florida, Gainesville, 1995.

[2] N. D. Levine, "Veterinary Protozoology,” Iowa State University Press, Ames, 1985.

[3] C. K. Harper and B. L. Penzhorn, "Occurrence and Diversity of Coccidia in Indigenous, Saanen and Crossbred Goats in South Africa," Veterinary Parasitology, Vol. 82, No. 1, 1999, pp. 1-9. doi:10.1016/S0304-4017(98)00266-0

[4] K. Z. Cai and J. L. Bai, "Infection Intensity of Gastrointestinal Nematodosis and Coccidiosis of Sheep Raised under Three Types of Feeding and Management Regimes in Ningxia Hui Autonomous Region, China,” Small Ruminant Research, Vol. 85, No. 2, 2009, pp. 111-115. doi:10.1016/j.smallrumres.2009.07.013

[5] T. M. Craig, "Epidemiology and Control of Coccidia in Goats," Veterinary Clinics of North America: Food Animal Practice, Vol. 2, No. 2, 1986, pp. 389-395.

[6] R. C. Chhabra and V. S. Pandey, "Coccidia of Goats in Zimbawe,” Veterinary Parasitology, Vol. 39, No. 3-4, 1991, pp. 199-205. doi:10.1016/0304-4017(91)90036-U

[7] L. J. M. Kusiluka, D. M. Kambarage, L. J. S. Harrison, C. J. Daborn and R. W. Matthewman, "Prevalence and SeaSonal Patterns of Coccidial Infections in Goats in Two Ecoclimatic Areas in Morogoro, Tanzania,” Small Ruminant Research, Vol. 30, No. 2, 1998, pp. 85-91. doi:10.1016/S0921-4488(98)00092-3

[8] C. C. Norton, "Coccidia of the Domestic Goat Capra hircus, with Notes on Eimeria ovinoidalis and E. bakuensis syn. E. ovina) from the Sheep Ovis aries,” Parasitology, Vol. 92, No. 2, 1986, pp. 279-289. doi:10.1017/S0031182000064052

[9] A. K. Soe and W. E. Pomroy, "New Species of Eimeria (Apicomplexa: Eimeriidae) from the Domesticated Goat Capra hircus in New Zealand," Systematic Parasitology, Vol. 23, No. 3, 1992, pp. 195-202. doi:10.1007/BF00010872

[10] E. Fox, J. Kuo, L. Tilling and C. Ulrich, "SigmaStat Statistical Software,” Jandel Scientific, San Rafael, 1994.

[11] S. Lloyd and E. J. L. Soulsby, "Survey of Parasites in Dairy Goats," American Journal of Veterinary Research, Vol. 39, No. 6, 1978, pp. 1057-1059.

[12] J. D. Lima, "Prevalence of Coccidia in Domestic Goats 
from Illinois, Indiana, Missouri and Wisconsin,” International Goat and Sheep Research, Vol. 1, No. 3, 1980, pp. 234-241.

[13] M. Ashraf and K. H. Nepote, "Prevalence of Gastrointestinal Nematodes, Coccidian and Lung Worms in Maryland Dairy Goats," Small Ruminant Research, Vol. 3, No. 3, 1990, pp. 291-298. doi:10.1016/0921-4488(90)90046-9

[14] B. L. Penzhorn, M. C. Rognile, L. L. Hall and S. E. Knapp, "Enteric Coccidia of Cashmere Goats in Southwestern Montana, USA," Veterinary Parasitology, Vol. 55, No. 1-2, 1994, pp. 137-142. doi:10.1016/0304-4017(94)90064-7

[15] A. Ruiz, J. F. Gonzalez, E. Rodriguez, S. Martin, Y. I. Hernadez, R. Almeida and J. M. Molina, "Influence of Climatic and Management Factors on Eimeria Infections in Goats from Semi-Arid Zones,” Journal of Veterinary Medicine, Vol. 53, No. 8, 2006, pp. 399-402. doi:10.1111/j.1439-0450.2006.00985.x

[16] P. W. N. Kanyari, "Coccidiosis in Goats and Aspects of Epidemiology,” Australian Veterinary Journal, Vol. 65, No. 8, 1988, pp. 257-258. doi:10.1111/j.1751-0813.1988.tb14314.X

[17] M. N. Abo-Shehada and H. A. Abo-Farieha, "Prevalence of Eimeria Species among Goats in Northern Jordan," Small Ruminant Research, Vol. 49, No. 2, 2003, pp. 109-113. doi:10.1016/S0921-4488(03)00078-6

[18] P. W. N. Kanyari, "Experimental Infections with Coccidiosis and Serum Antibody Quantification in Two Breeds of Goats," Veterinary Parasitology, Vol. 28, No. 1-2, 1988, pp. 11-18. doi:10.1016/0304-4017(88)90014-3 